\title{
A Toolkit for Evaluating the Design and Implementation of European Union Security and Defence Policy Mandates
}

\author{
Michael Merlingen ${ }^{1}$ \\ ${ }^{1}$ Department of International Relations and European Studies, Central European University, Hungary \\ Correspondence: Michael Merlingen, Department of International Relations and European Studies, Central \\ European University, Nador u.9, 1051 Budapest, Hungary. E-mail: merling@cu.hu
}

Received: March 12, 2013 Accepted: July 3, 2013 Online Published: July 5, 2013

doi:10.5539/res.v5n3p41 URL: http://dx.doi.org/10.5539/res.v5n3p41

\begin{abstract}
The paper elaborates a toolkit for the systematic assessment of CSDP operations. It is derived from international relations theories and enables analysts to go beyond existing evaluation research of the CSDP, which is largely ad hoc and idiosyncratic in character. The kit classifies operations on the basis of their mandated activities. Common Security missions perform three roles: bargaining, arguing and information brokerage. These roles can be further broken down into specific actions: deterrence, compellence, facilitation of EU conditionality, mentoring, advising, training, monitoring and mediation. Drawing on IR theories, the toolkit identifies conditions that enable the successful completion of these actions. The paper uses examples to illustrate how the toolkit can be used to evaluate to what extent the roles assigned to CSDP operations by Brussels match the scope conditions present in theatre; to what extent Brussels has equipped its operations with the required role-specific policy instruments; and to what extent mission managers (in Brussels and in theatre) are successful in organising the means they have been given to increase the likelihood of successful mandate implementation.
\end{abstract}

Keywords: CSDP operations, EU mandates, evaluation, conditionality

\section{Introduction}

Evaluations of European Union Common Security and Defence Policy (EU CSDP) missions have traditionally been given little attention by interested analysts and scholars. Their focus instead has been on the institutional development, capability and politics of the CSDP. Nonetheless, mission evaluations have lately become more salient. Undoubtedly, this has to do in part with the growing number of CSDP deployments. The EU has also been busy improving its in-house capacity for evaluating on-going CSDP missions and for identifying lessons-learned that can be applied to future deployments. Independent policy analysts and academics have meanwhile evidenced increasing interest in evaluating CSDP operations from a more disinterested perspective.

While this is a welcome development, scholarly and other independent evaluations have with a few notable exceptions proceeded without any clear theoretical framework. The state-of-the-art of CSDP evaluation is thus a challenge to academia and a problem for the EU. The lack of theory has stunted the development of generalizable explanations of variations in mission performance, the generation of predictions about likely mission performance and the formulation of valid prescriptions concerning how to improve CSDP operations. This article seeks to contribute to recent efforts to develop conceptual toolkits to evaluate CSDP operations. It focuses on official mandates in order to evaluate their design, operationalisation and implementation.

The article is organized into three parts. It begins by reviewing existing evaluations of CSDP operations and highlights their often ad hoc and idiosyncratic nature. This characteristic is attributed to a lack of theory in such work. Thereafter, the analysis outlines a conceptual toolkit for evaluating CSDP missions and explains its functions and use. The evaluative approach is based on a comprehensive list of roles assigned to and performed by CSDP missions. The evaluative frame provided reviews the scope conditions under which these roles can be expected to be enacted successfully. These conditions constitute a yardstick by which the design and implementation of mission mandates can be assessed. Empirical examples, which draw on the author's interview data gathered in Brussels and on document analyses, are used throughout to show how the toolkit may be applied and to illustrate the insights it generates. 


\section{CSDP Evaluations: The Status Quo}

Independent assessments of CSDP operations focus on single missions, on multiple missions deployed in one country (such as the Democratic Republic of Congo) or in a region (such as the Western Balkans), on certain types of missions (such as police missions) or, finally, on all EU deployments. Equally varied are the yardsticks analysts use to assess the successes and failures of CSDPs. They range from the completion rates of the security sector reform projects carried out by missions to the scope and depth of the actual transformations in the local security sector that can be attributed to CSDP missions and the impact of missions on the EU's geopolitical standing in the concerned country or region. The resulting scorecards of EU operations differ widely. For instance, a former head of the European Defence Agency (EDA) who has since become a policy analyst specialising on the CSDP, argued that the problem with 'the CSDP's operational record as a whole is its lack of ambition' and that many civilian operations 'have been so small as to be little more than political gestures; and the military operations have been so carefully circumscribed in mission and duration that their impact has been equally limited.' (Witney, 2008: 41). In a major study for the International Institute for Strategic Studies, Bastian Giegerich offered a similar conclusion. He quoted an unnamed officer involved in planning military CSDP operations, who commented that 'sometimes it feels as if we are conducting missions to satisfy our conscience rather than achieve a certain effect on the ground' (Giegerich, 2008: 27). Michael Merlingen suggested that the 'overall record of CSDP missions is characterized by incompleteness, unevenness, and partial frustration' (Merlingen, 2012: 186). Reviewing the record of the CSDP in its first 10 years, Anand Menon criticised the EU for (ab)using the CSDP 'as an alibi for a tendency to avoid broader international security responsibilities' (Menon, 2009: 228). Asle Toje illustrated this charge with regard to Darfur. The civil war there, he claimed, was 'exactly the sort of question that the [CSDP] was created to handle' and yet the EU stood by as massacres of civilians and gross human rights violations were 'perpetrated by rag-tag guerrillas who almost certainly would have proven no match for professional soldiers' (Toje, 2008: 128, 35). From a U.S. perspective, Kori Schake has been equally unimpressed by the CSDP. She claimed that by 'choosing marginal activities, the EU has actually increased scepticism about its seriousness of purpose rather than built a foundation for more complex and demanding [CSDP] undertakings' (Schake, 2006: 105). In contrast, a Rand-team offered a distinctly positive assessment of CSDP achievements. Looking at both CSDP missions and non-CSDP peace missions led by EU states, the Rand evaluation argued that these missions established 'a short but respectably positive record in the field' (Dobbins, et al., 2008: xxxiv; Dobbins, 2008). Another RAND study exclusively devoted to CSDP operations concluded that the EU 'is capable of making a real contribution to the civilian dimension of post-conflict stabilization and reconstruction' (Chivvis, 2010: 39). CSDP expert Jolyon Howorth offered what is perhaps the most positive assessment of the CSDP. He argued that the operations 'certainly amount to an important new development, from which the EU is learning all the time and going from strength to strength' (2007: 240) (Note 1). Replicating this pattern of idiosyncratic assessments, recent edited volumes that were either devoted to or gave considerable space to explorations of the CSDP mission record, provided readers with similarly diverse judgements of the effectiveness of CSDP operations (Grevi, et al., 2009; Merlingen \& Ostrauskaite, 2008).

The diversity of existing evaluations of CSDP operations is indicative of a broader analytical problem. While these analyses offer insightful commentaries on CSDP operations, they are mostly of an ad hoc and sui generis character since they are produced in the absence of a clearly defined framework that could discipline the assessments, make them comparable and provide analysts with both explanatory and (ideally) predictive leverage concerning which CSDP operations are most likely to succeed. Furthermore, by not 'doing theory', this body of research has yielded few generalizable propositions. The manifold lessons-learned it has identified cannot be taken to be reliable guides to secure more effective missions. This unsatisfactory state of affairs has only recently begun to be addressed. Drawing on theories about the changing nature of states in the EU and about the proliferation of new post-Westphalian security threats, Emil Kirchner and James Sperling developed a sophisticated framework centred on the concepts of prevention, assurance, protection and compellence to evaluate the EU's contribution, including through the CSDP, to European security governance (Kirchner \& Sperling, 2007) (Note 2). The most comprehensive analytical framework to date to study the difference that CSDP has made in EU and international politics is laid out in the recent book by Roy Ginsberg and Susan Penksa. Conceptualising CSDP as a component of the EU foreign policy decision-making system, they examine the former's impact in terms of an original typology that distinguishes between five types of external effects, ranging from the political influence of operations on the foreign policy and domestic politics of host countries to 'how and why operations evolve over time and to the effects after operations terminate' (Ginsberg \& Penksa, 2012: 130). This article contributes to the emerging debate about theory-informed assessments of CSDP 
operations by introducing its own evaluation toolbox. At this stage in theory development, creating competition among different assessment strategies is as important as fine-tuning and applying existing strategies.

\section{The Toolkit, What It can Do and How to Use It}

The toolkit laid out in this article is based on CSDP mandates. Drawing on the sociological concept of role, it breaks down mandates into a series of mission roles and associated functions or actions. The article identifies three generic roles that cover the Common Security repertoire of activities. In the role of bargainers, CSDP operations may engage in deterrence, compellence or the facilitation of EU conditionality. In the role of arguers, they may engage in mentoring, advising or training activities. Finally, in the role of information brokers, they may engage in monitoring and mediation. Together these roles and functions are exhaustive of the activities carried out by CSDP operations. Roles and functions are either explicitly assigned to missions by their mandates or are implied in a manner analogous to the implied powers of the EU (Note 3). The advantage of thinking about CSDPs in terms of these roles and functions is that there is a sophisticated, theoretically informed international relations literature hat identifies and discusses the scope conditions under which actors are likely to succeed in enacting these roles and carrying out these functions. With only a few adjustments, CSDP evaluators can use these scope conditions to determine whether the EU has given its missions roles that are suitable for the exogenous or structural scope conditions present in the theatre of operations; whether the EU has provided its missions with the appropriate, role-specific tools to carry out their functions; and whether missions have organised themselves in a manner conducive to the most effective use of their policy tools. To carry out such an assessment, the evaluator must identify the roles and functions assigned a specific CSDP via a review of its mandate and determine appropriate scope conditions for success in that role type via a review of the relevant international relations literature.

The toolkit is suitable for implementation-based rather than results-based evaluations. This is both a strength and a weakness. A key advantage of the toolkit is that it generates practical information that decision-makers can employ to improve CSDP operation design and management. A disadvantage of the approach is that its baseline is the official mandate of a given mission. But many analysts argue that CSDPs suffer from overly easy mandates, which prevent missions from becoming a more powerful force for good in world politics. Another disadvantage of the toolkit is that it can only offer partial insights into the in-theatre impact of missions, which is affected by additional factors besides mission design and management. In view of these limitations, the toolkit is best viewed as a basic component of a still-to-be-developed more comprehensive evaluation framework.

\section{CSDP Operations and Bargaining Theories}

Bargaining has long been a key concept in international relations. In the most general sense, international bargaining refers to policy coordination among interdependent actors with conflicting interests (Fearon, 1998). A key element in such coordination is a verbal or non-verbal communication process, say, the mobilisation of a country's armed forces. Jon Elster has usefully defined bargaining as a 'process aimed at forcing or inducing interlocutors to accept one's claims. To achieve this end, bargainers rely on threats and promises' (Elster, 1991). As this quote suggests, international bargaining comes in two basic forms, depending on whether those engaged emphasise punishment or benefit (Note 4): coercive and cooperative. The 'general idea of coercive diplomacy is to back one's demand on an adversary with a threat of punishment for non-compliance that he will consider credible and potent enough to persuade him to comply with the demand' (George, 1997: 4; George \& Simons, 1994; Schultz, 2004; Fearon, 1994). During the Cold War, scholars developed coercive bargaining theories, notably deterrence and compellence theories, to study the strategic relationship between the United States (U.S.) and the Soviet Union and conflicts, conflict management and conflict resolution more generally (besides George, see especially Schelling, 1990; 2008). Unlike realist international theory, with which it was associated, coercive bargaining models have not seen their fortunes decline in the post-Cold War era. Both deterrence and compellence have gained in importance in the post-Cold War era of military unipolarity (Jakobsen, 1998; Art and Cronin, 2008). The targets of these strategies are rogues, i.e., actors at the margins of Western-dominated internationals society. Rogues may be states, such as North Korea or Iran, or they may be non-state actors, such as Al Qaida or other groups serving as spoilers in peace processes. Coercive diplomacy relies on sanctions (visa, economic, etc.) or military force. In both cases the demander issues a threat to the opponent, a threat that may be coupled with measures that inflict a limited amount of pain on the opponent, to induce compliance. In the wake of the end of the Cold War, the EU has increasingly used coercive diplomacy in its foreign policy.

With the creation of the CSDP, the Union considerably enlarged its capability to engage in coercion. By equipping itself with autonomous military capabilities, the EU has given itself the tools to engage in military deterrence and compellence. Scholars of nuclear diplomacy initially developed theories of the dynamics of these 
military strategies. As international conflict management and resolution agendas expanded following the Cold War, the concepts and thinking underpinning these theories have been adapted to study domestic conflicts and peacekeeping (broadly defined), especially the conditions, roles and functions of third-party interveners in protracted conflicts. The EU has used the military CSDP to beef up its role as peacekeeper and peacebuilder.

In cooperative bargaining, the demander promises benefits in exchange for compliance with its demands. This is a form of positive conditionality, which is concerned with 'the use of incentives to alter a state's behaviour or policies' (Checkel, 2000: 1). During the Cold War the use of positive conditionality in interstate relations was constrained by the bipolar structure of international political blocs, which favoured coercive over cooperative bargaining strategies. Following the Cold War, positive conditionality policies have proliferated and become ever more intrusive. They have become part of the armoury of international organisations too, including the United Nations and the African Union, which use them to advance international peacebuilding and statebuilding goals. The EU has become an avid user of this approach. It primarily applies positive conditionality in its enlargement, association, economic development and democracy-promotion policies. 'The dominant logic underpinning EU conditionality is a bargaining strategy of reinforcement by reward, under which the EU provides external incentives for a target government to comply with its conditions' (Schimmelfennig \& Sedelmeier, 2004: 662; Grabbe, 1999). If the target fails to comply, the Union simply withholds the reward. While CSDP operations typically do not have the authority or means to impose specific conditions on host countries, they often do play the role of conditionality facilitator for the EU.

Rational models dominate bargaining analyses. Adherents of these approaches explain negotiation conduct and outcomes in terms of the cost-benefit calculations of the bargainers. These models presuppose that actors are minimally rational, i.e., that at a minimum opportunity costs enter into their decision processes. Moreover, most models are informed by materialist theories of social action that emphasise material threats and side payments as central to understanding bargaining processes. However, the use of social power is equally compatible with coercive bargaining theories.

\subsection{The Deterrence Role of CSDP Operations}

Deterrence has been a central concept of international relations for many decades and analysts have developed intricate models of its dynamics. Those, in turn, have engendered robust criticism (Freedman, 2004; Jervis, et al., 1985; Zagare \& Kilgour, 2000; Morgan, 2003). Deterrence theory remains an important international relations approach. In general terms, deterrence is 'about the role of threats in international affairs, and in particular threats of force, intended to stop others acting in harmful ways' (Freedman, 2005: 769; for an historical overview and its continued relevance, see Long, 2008). By issuing a well-calibrated threat, the deterrer signals its target that the costs for taking a given course of action will exceed the expected benefits.

Importantly, deterrence is now routinely applied to relationships in which one actor is not a state, such as between a state and pirates. In peace and conflict studies, the logic of deterrence has been found useful for analysing the prevention or limitation of mass atrocity crimes in intra-state conflicts and their prosecution through the use of international law and its organs, notably the International Criminal Court. More important for the purpose of this argument, the logic of deterrence has been applied to two important challenges faced by international peacebuilding: the commitment problem and spoiling. The former refers to the argument that combatants in a civil war find it difficult to commit credibly to peace, even if they wish to do so, because once they lay down their weapons, 'it becomes almost impossible to either enforce future cooperation or survive attack' (Walter, 1997: 336). Spoiling refers to groups with devious objectives 'that actively seek to hinder, delay, or undermine conflict settlement' (Newman \& Richmond, 2006: 1). An outside third-party can use deterrence to enable parties to an intra-state conflict to commit credibly to cooperation by reducing their security concerns, and to prevent spoilers from disrupting the peace process by threatening them with punishment if they engage in conduct that undermines the peace process (Stedman, 2000; Greenhill \& Major, 2006/7; Walter, 2001; Stedman, 1997). EU officials routinely assign CSDP military missions deterrence roles.

The general literature on coercive bargaining identifies a series of secondary conditions under which the use of deterrence can be expected to succeed. They include numerous factors, including the balance of interests among the 'deterrer' and the 'deteree' and legitimacy of the deterrer's demands. While there is considerable disagreement among scholars about which of these secondary matters influences, and how much, the success rate of deterrence, there is broad agreement that there are three necessary conditions without which deterrence cannot work. These principal scope conditions for successful deterrence are that the deterrer has sufficient power (material or social) relative to the deterree, has the interest to carry out the issued threat and demonstrates a clear and credible commitment - resolve - to do so. To demonstrate resolve, costly action may have to be taken by the 
deterrer in order to impress on the target that the threats are not simply talk.

The deterrence framework and the scope conditions it identifies are a useful tool to evaluate CSDPs. Take the military CSDP operation in Bosnia, codenamed EUFOR Althea (2004). The Union assigned the mission a deterrence mandate (Council of the European Union, 2004a). At the same Brussels put in place the scope conditions necessary for the successful enactment of the role. To enable EUFOR to maintain the peace in Bosnia and deter any spoilers of the peace accord, notably the former armed forces of the warring factions, Brussels endowed the operation with robust capabilities. The EU's largest-ever CSDP military operation initially had the same number of troops as the preceding NATO peacekeeping force, 7,000 men and women. Furthermore, the EU designed the mandate so as to demonstrate its political commitment to act, if necessary, on its deterrent threat. The EU gave Althea an open-ended, rather than time-limited, mandate, and it was constructed as a Berlin Plus operation launched in co-operation with NATO and the U.S. The NATO and U.S. connections were important given the EU's low international standing in Bosnia at the time, which was primarily due to its disastrous failure in the 1990s to stop the ethnic violence in the country. By linking Althea to NATO and the U.S., the EU enabled EUFOR to benefit from their credibility in the region. Moreover, to demonstrate to anyone considering violating the Dayton Peace Accord that the CSDP operation was no less committed to maintaining peace, whatever the costs, than the alliance had been, the EU intentionally modelled Althea's objectives, force structure and deployment area on that of the preceding NATO peacekeeping force. The EU force even had a NATO-look-alike armed constabulary force for executive policing functions, the Integrated Police Unit (IPU), which was made up mostly of Italian Carabinieri. Last but not least, the EU raised the opportunity costs of failure for itself in Bosnia, by suggesting that Althea would make or break the idea of the military CSDP. The stakes could thus not have been higher for the Union. In short, Brussels did an excellent job in providing EUFOR Althea with the scope conditions needed for successfully carrying out its deterrence mandate. Its unblemished record of maintaining the peace in Bosnia is no accident.

\subsection{The Compellence Role of CSDP Operations}

The concept of compellence has the same genealogy and logical structure, as the concept of deterrence. Moreover, both types of coercive bargaining have similar conditions of success. The same scholars that developed the concept of deterrence developed the idea of compellence. Yet, the notion of compellence has enjoyed considerably less academic attention (for recent discussions, see Art and Cronin, 2008; Schaub, 1998; Sechser, 2010; for the connection between compellence and deterrence, see Sperandei, 2006). Just like deterrence, compellence is a form of coercive diplomacy, which works by changing the cost-benefit calculus of targets. But whereas deterrence is about preventing targeted actors to begin engaging in harmful behaviour, compellence typically involves the infliction of a small amount of damage to a target's interests, coupled with the threat to escalate that harm in order to persuade the target to end or change an undesired action already under way. Thus, just like deterrence, compellence requires of the actor engaging in the action to have sufficient power (material or social) relative to the opponent and to credibly commit to using it to achieve the compellence purpose.

The notion of compellence is now often employed to study peace missions, the use by an outside third party of military or non-military means to coerce spoilers to stop disrupting the peace process (in addition to the literature cited on deterrence and peacebuilding, see de Jonge Oudraat, 2008; Oliver, 2002). Actions may include the enforcement of a no-fly-zone or disruption of the assets of targeted governments or parties (Williams, 2010). The same peace mission may pursue both deterrent and compellent policies. Compellence has become a standard strategy in military CSDP operations (cf. Kirchner \& Sperling, 2007; Dominguez, 2011).

To continue with the example of EUFOR Althea, while its mandate did not task it explicitly with performing a compellence role, it did charge the mission with providing 'compliance with the responsibility to fulfil the ... General Framework Agreement for Peace' (Council of the European Union, 2004a). This formulation gave the Force Commander the implied authority to engage in compellent actions if he saw it necessary to ensure a safe and secure environment or to advance what the Concept of Operations called the key supporting tasks, i.e., tasks the pursuit of which 'contributes to the accomplishment of the main military mission' (Bertin, 2008: 68). In particular, the first Force Commander, General David Leakey, used this language as justification to engage in compellence to advance key supporting tasks. He managed to create the right scope conditions for the strategy, demonstrating EUFOR Althea's capability and resolve to hurt spoilers of the peace to stop their undesired actions. At the same time, Leakey was handicapped by the absence of a scope condition that affects the effectiveness of compellers but not of deterrers.

To emphasize that he was serious about compelling spoilers of the peace in Bosnia to cease their subversive 
activities, General Leakey demonstratively and proactively used his powerful manoeuvre forces, which could be deployed at short notice. He ordered his troops to carry out a number of coercive actions aimed at disrupting networks of former fighters and war-crime suspects and constraining them to stop engaging in black-market activities to finance their hard-line ethno-political agendas and to support war crime fugitives such as Karadžić and Mladić. Concretely, Leakey employed EUFOR to conduct organised crime-busting operations, to reinforce local border guard patrols and to seize control of all underground military facilities throughout Bosnia, which had served as hide-outs for opponents of the international presence in the country (Bertin, 2008). These measures yielded mixed results. On the one hand, EUFOR demonstrated its commitment to go after spoilers unless they stopped their activities. EUFOR limited the activities of the clandestine networks of war crimes fugitives and the associated organised crime, and it prompted local police to take a bolder stance against these spoilers of the international state building project. Yet while degraded, the organised crime and ethno-political complex persisted and continued its undesirable activities. The resilience of these elements demonstrated Althea's limitations. A scope condition for compellence is the capability of the compeller to identify the target and direct punishment against it. EUFOR Althea only had a limited capacity to do so. The large majority of its troops were neither trained nor equipped for clamping down on organised crime, nor were they suited for the task of ferreting out the corrupt politicians associated with the crime networks. These are typical police tasks. This pinpoints a mismatch between, on the one hand, EUFOR's policy tools and capabilities and, on the other, is implied mandate objective. Brussels failed to equip EUFOR with a more powerful gendarmerie force, which would have given General Leakey the means to be more effective in policing Bosnia's spoilers and in compelling them to cease their illicit activities. That said, a serious downside of so equipping EUFOR is that it likely would have undermined the work of the civilian CSDP police mission in the country, whose mandate emphasised the role of arguer. As will become apparent below, the scope conditions for successful arguing are very different from those for effective compellence. The more general point is that in the case of parallel CSDP interventions in a country, or multi-dimensional missions assigned more than one role by their mandates, analysts have to ask to what extent these roles and the scope conditions for their successful performance are compatible.

The capability to coerce parties to a conflict to stop engaging in what international conflict managers or peacebuilders consider undesirable action does not rest with military assets alone. Such coercive capacity may originate from social power as well - the individual or collective capability to construct social reality (Adler, 2010) (Note 5). CSDP missions can thus be assessed in terms of how well they succeed in creating and leveraging social influence.

The EU Monitoring Mission (EUMM) in Georgia (2008) has been quite successful in employing social power for compellence purposes. Although the EUMM has a much narrower mandate and significantly less material benefits to offer Tbilisi than the EU delegation in the country, the EUMM has on some issues become politically more influential than the EU delegation. The EUMM leadership achieved this feat by successfully mobilising social power to issue a credible compellent threat in negotiations with Georgian authorities. It stressed that unless Tbilisi stepped up its cooperation with the mission, it would recommend to Brussels to downsize its deployment in the country, thereby reducing the international salience of the territorial conflict between Georgia and the breakaway territories. The mission leadership created the conditions for successful compellence by, firstly, instrumentalising the fact that it is one of Tbilisi's top foreign policy priorities to keep the Georgian-Russian conflict over Abkhazia and South Ossetia on the international agenda and, secondly, by presenting the EUMM as possessing the strategic capability and the political willingness to use its institutional ties with Brussels to convince the member states to carry out the issued threat of downsizing the mission. A condition facilitating this instance of successful compellence was that the head of the EUMM at the time was a senior diplomat from Germany, one of the big-three EU countries, with excellent connections to his foreign ministry. This further strengthened the credibility of the threat issued by the mission. The upshot of the EUMM's successful exercise of social power was that it compelled a reluctant Georgian government to stop its practice of freely moving its military and law enforcement personnel in and out of the areas adjacent to the administrative boundary lines separating the country from South Ossetia and Abkhazia. The mission signed two parallel agreements with the Georgian ministries of internal affairs and defence, which granted it far-reaching powers to supervise and enforce compliance with limitations on the positioning of Georgian military and police forces and equipment in the sensitive areas. Conversely, in the absence of appropriate scope conditions for the use of coercive bargaining power (material or social), the EUMM has not been able to compel the leaders of the breakaway republics and of Russia to allow it to act on its mandate to carry out monitoring tasks throughout the territory of Georgia, i.e., on both sides of the administrative boundary lines separating Georgia proper from South Ossetia and Abkhazia. This failure underscores that Brussels mandated the EUMM to carry out certain tasks without giving it the proper tools to do so. 


\subsection{The Conditionality Role of CSDP Operations}

The bargaining model of conditionality is similar to compellence in that it seeks to constrain interlocutors to change their behaviour to accord with the expectations of the compeller. The EU employs two broad types of foreign policy conditionality: that linked to enlargement and those coupled with specific policies (Trauner, 2009; Steunenberg \& Dimitrova, 2007; Grabbe, 2006; Vachudova, 2005). Both work not by threatening punishment, but by promising rewards for compliance. The former links progress on the road to EU membership to the implementation of domestic reforms. The latter ties the implementation of domestic policy changes to certain benefits such as a visa-free travel to the EU or improved access to Union markets. The bargaining model of conditionality argues that a state complies with the demands of the conditioning actor if the benefits of the rewards exceed their adoption costs. These cost-benefit calculations, and thus the effectiveness of conditionality policies, are shaped by a number of scope conditions (Schimmelfennig \& Sedelmeier, 2004; Schimmelfennig, 2008).

CSDPs do not formally possess the capability to devise their own conditionality policies to incentivise locals to carry out costly peacebuilding reforms. However, in virtually all Common Security operations, the role of conditionality facilitator is implied because the standard CSDP mandate asks its personnel to contribute to the EU's comprehensive approach to reform the target country and to ensure consistency with the external activities of the European Commission. Hence, missions can be evaluated on how well they perform this role. Moreover, CSDP operations that manage to organise and conduct themselves so as to render EU conditionality more effective enhance their own influence vis-à-vis local authorities and with the Commission. Increased influence, in turn, enhances the likelihood of successful mandate implementation, both by boosting missions' ability to overcome local resistance to reforms and by securing higher funding from the Commission for mission reform projects. (Note 6) The skill with which CSDP operations play the role of conditionality facilitator is thus an important yardstick for evaluating the quality of mission management. Such evaluations can zero in on a number of issues.

To begin with, it is a basic scope condition for successful conditionality that the stipulated requirements are spelled out clearly. Missions can be assessed on how well they leverage their expertise as security sector reformers and their in-depth knowledge of, and privileged access to, the local security sector to assist the European Commission in fine-tuning the determinants that shape the cost-benefit calculations that local actors make in deciding whether to comply with EU conditionality demands. As part of such an assessment, evaluators have to look at how well mission managers succeed in operationalizing their mandates so that their activities are directly relevant to what the European Commission expects from the country's security sector actors. Achieving programmatic complementarity between mandate objectives and EU conditionality is one thing. Creating synergy from that complementarity is another, and altogether different, thing. Only if mission managers are able to translate complementarity at the programmatic level into synergies at the task level can they expect their staff to acquire the issue-specific expertise they need to play the role of European conditionality facilitator effectively. For instance, the mandate of the police mission EUPOL Proxima in Macedonia (2003-2005) was closely aligned with EU accession conditions for the nation, and the European Commission was actively involved in Macedonian police reforms (Flessenkemper, 2008: see also the Commission's Stabilisation and Association reports). The shared objectives appeared to create optimal conditions for the mission to work closely with the Commission to help it fine-tune its conditionality policies. Yet this did not happen. During its first year of operation the mission leadership in theatre failed to transform the common objectives of the mission and of Commission-managed EU conditionality into fruitful cooperation between the two EU actors and a credible mission performance as conditionality facilitator. The mission did not operationalize its objectives so as to ensure its activities supported EU conditionality. Rather than agreeing strategically on a focused selection of reform projects, Proxima experts instead initially provided ad hoc advice based on their own views concerning how to improve Macedonian policing (Note 7). Second, successful conditionality depends on the local authorities understanding precisely what they have to do to comply with EU expectations. Evaluators can ask whether CSDP operations do a good job in assisting locals in understanding EU conditionalities in the security sector? Third, a critical factor influencing the effectiveness of EU conditionality is the speed with which a country is rewarded if it complies with Union conditions. Do CSDP operations help the European Commission speed up the delivery of rewards by providing it with timely and accurate feedback about a target's compliance record? Through being co-located with local police personnel, CSDP operatives enjoy an unrivalled capacity to monitor the extent EU conditionality policies are translated into concrete change in day-to-day work in the security sector. Do they leverage this information advantage? Finally, targeted actors will only comply with the terms of conditionality policies if the costs of adopting them do not outweigh the promised benefits. These costs 
are determined by, among other things, the balance of preferences among the relevant local actors. Evaluators can ask whether CSDP operations manage, through their training, mentoring and other outreach activities, to influence the preferences within the local security sector and build support among its professionals for the EU conditions (reforms) in question, i.e., whether missions succeed in becoming preference-changers? For instance, through the mentoring activities of its co-locators and outreach to the local police unions, the police mission, EUPM, in Bosnia (2003-2012) made the case to the rank and file as well as mid- and senior-level police managers that the controversial EU demand of creating a centralised police structure spanning the Bosnian Serb Republica Srpska and the Muslim-Croat Federation was in the best interest of the local police. Yet the EUPM did not manage this task well and the campaign was not successful. The mission failed to get its own staff fully behind the campaign, which some staff members considered being too political, and it engaged in insufficient coordination with the Office of the High Representative (OHR), whose head was double-hatted as EU Special Representative (EUSR). The EUPM and the OHR/EUSR often gave different messages on police reform to local authorities and police officers, which undermined the impact of the messages (Mühlmann, 2007; 2008). This points to an important generic factor affecting the performance of CSDP operations: unity of purpose among the members of the EU family. The general point to be made here is that analysts wishing to evaluate mission performance can take each of the four scope conditions shaping the effectiveness of EU conditionality policies and examine whether CSDP missions have managed to facilitate the operation of these policies. If the answer is yes, a follow-up question is whether missions have as a result benefited from greater Commission largesse when it comes to funding mission projects and greater influence with locals than could be expected if they had not done well as EU conditionality facilitator. This requires counter-factual arguments or a comparative research design that looks at CSDP missions, which did well as EU conditionality facilitator and at missions that did not do well.

\section{CSDP Operations and the Theory of Communicative Action}

Unlike bargaining theory, the theory of arguing is a recent import into international relations and EU studies. Thomas Risse introduced the approach into English-language international relations scholarship only a little more than a decade ago (Risse, 2000; for a recent elaboration, see Schmidt, 2010a). Drawing on Habermas' theory of communicative action, Risse approached the logic of arguing as a distinct mode of social action, different from the logic of consequences, which underpins bargaining models, and from the logic of appropriateness, which refers to the taken-for-grantedness underpinning the behaviour of actors socialised into a particular way of life. Bargaining and arguing theories have different conceptions of language and its role in social interaction. Bargaining theories view language as a strategic tool used by speakers to influence interlocutors in a desired direction. In Habermas' words, language is a means 'to bring opponents to form or to grasp beliefs and intentions that are in the speakers' own interest' (Habermas, 1984: 95). Conversely, a key feature of communicative action is that is it discursive. Actors draw on language to 'step back from the interaction, in order to reflect upon it, and debate its reasonableness' (Edgar, 2006: 25).

To enter into a debate - to argue - is to try to persuade an interlocutor to 'change beliefs about factual or normative matters' (Elster, 1991). Moreover, it is constitutive of arguers that they are willing to make their preferences and causal beliefs about how to realise them central to communicative interaction. In such discussions, the main thing that counts is the power of the better argument. Material power differentials recede into the background (Risse, 2000). Arguing involves a deliberate process of reason-giving (Eriksen, 2005b). It presupposes actors who are reasonable, i.e., whose decisions are based on notions of fairness and appropriateness. Though not theorised in terms of communicative action, conflict resolution approaches have traditionally emphasised the importance of argumentation and persuasion, say, in the form of multi-track diplomacy and peace workshops. The theory of communicative action has been applied in EU studies too in recent years (Eriksen, 2005a; Sjursen, 2004; 2006). The scope conditions for effective communication highlighted by the theory can be employed to evaluate CSDP mission design and management.

The role of arguer is part and parcel of the role repertoire of CSDP operations, although it is more often implied by mandates than explicitly assigned. A frequent mission objective is to reform the local security sector. On some occasions, operations may be able to use compellence or to instrumentalise EU conditionality to constrain or incentivise locals to undertake desired reforms. On other occasions, missions may have to rely on argumentation to implement their mandates. Indeed, for many operations, arguing will be the only available tool. The literature on arguing has identified a number of conditions under which such efforts may successfully change the preferences and causal beliefs of interlocutors. The conditions refer to the institutional setting in which argumentation occurs; the social distance between the lifeworlds of the arguers; and the mode of language use.

Risse and Klein have argued that settings that stress the professional authority of arguers and the importance of 
professional norms and procedures are conducive to successful argumentative persuasion (Risse \& Kleine, 2009: 12). So are settings that allow for intense interaction between arguers and their targets over a long period (Lewis, 2005). Analysts have also suggested that the social distance between persuaders and persuadees depends on how different the lifeworlds of the interlocutors are, i.e., to what extent they share background ideational characteristics (Schmidt, 2010b). The thicker the shared background, the more likely it is that argumentation will flourish and yield changes in preferences and/or beliefs about how to achieve them. Finally, the mode of language use matters. The more the arguers slide into the role of demanders and the less open they are to deliberative argumentation based on reason-giving and a readiness to redeem validity claims when challenged, the less likely it is that they will succeed in bringing about changes in the thinking of their interlocutors (Checkel, 2001). Importantly, such dialogical interaction has to provide opportunities for listeners to challenge the assertion of speakers and for listeners to become speakers (Landwehr \& Holzinger, 2010).

The role of arguer in CSDP missions is comprised of three types of activities: mentoring, advising and training. CSDP training courses typically take place in academy-type settings in which trainees are placed in an environment in which professional norms of conduct and professional expertise prevail. EU experts either design or supervise the design of relevant course syllabi to ensure they are in line with best practice. The depoliticised setting and the expertise-based contents of CSDP trainings are conducive to argumentation. Yet mission management in Brussels and on the ground has been less successful in taking account of other scope conditions for successful argumentation. The mode of arguing has proven a challenge. Most of the training CSDP missions do is focused on senior and mid-level security sector personnel, mostly police officers, but also judges, prosecutors and prison personnel. These trainees have been socialised into their own national law enforcement and judicial cultures. Introducing and inculcating new professional norms and knowledge to these groups is unlikely to succeed unless the CSDP training is dialogically organised, involving a process in which internationals and locals exchange reasoned arguments (factual and normative) about what constitutes best practice in the local context. People who have learned to do their jobs well in a particular way need to be persuaded, rather than lectured, concerning why they ought to change their ways of knowing and doing things, in particular if their practices and habits have proven reasonably successful in the past. Yet cooperative or deliberative training is demanding, not least because it requires that CSDP professionals possess a good grasp of local professional norms, expertise and practices in order to engage in the give and take of argumentation. Mobilising trainers who know the local professional context has been a consistent challenge for CSDP missions, with the responsibility for this situation shared by member states, who are supposed to second well-trained and qualified experts to CSDP missions, and in-theatre mission management, which organises in-country training for its staff.

To illustrate how the scope conditions for successful arguing can be used to assess CSDP training operations, the article returns to the EUPM in Bosnia. It had considerable success in recruiting personnel familiar with the communist-style policing prevalent in the former Yugoslavia. Some EUPM experts hailed from former communist countries, others previously served in United Nations missions in the region. Also, the EUPM put in place an innovative phased induction programme for its new staff. EUPM personnel were thus well prepared to engage in communicative action with their local counterparts. The relative success of the EUPM as a change-maker of professional policing knowledge and norms in Bosnia, a success which stands in stark contrast to the stalemate on highly politicised issues such as police restructuring, testifies to the fact that if the right scope conditions for arguing are present in theatre, or created by the EU, training missions can effectively carry out their mandate (Merlingen, 2009). Conversely, the training mission EUJUST LEX Iraq has been bedevilled by problems. Prior to 2009, the training of Iraqi justice system personnel took place exclusively in EU states. While the mission helped national authorities design and deliver the training courses, the main input came from the organisers, who in most cases had little knowledge of Iraq. Training was thus reduced to lecturing trainees on how different EU states ran their justice sectors. Since 2010, the mission has deployed more experts to Iraq (Baghdad, Erbil \& Basra), where they not only organise in-country trainings, but also engaged in mentoring and advising. The ensuing close and regular contact with Iraqis has provided EU experts with hands-on knowledge of the local justice system and put in place one of the conditions for making the mission an argumentative change-maker. Yet given the highly politicised and violent environment in which the Iraqi justice system continues to operate, the ability of EUJUST to change professional norms and expertise through argumentation remains limited. Brussels designed a mission for Iraq that is largely unsuitable for the structural scope conditions existing on the ground: power struggles (violent and non-violent) outside and inside the security sector have not receded into the background, thus leaving little room for the better argument to shape how law is applied, interpreted and enforced by rule-of-law professionals. 
CSDP personnel who are engaged in mentoring and advising activities are typically co-located with local security sector personnel. Co-location creates small-group, face-to-face interaction between EU experts and local interlocutors and is thus well suited to the CSDP arguing role because it foregrounds workplace norms and professional expertise. In addition, it provides for an intense and often long-lived relationship between interlocutors. Yet, just as in the case of training, there are differences in how well CSDPs do in creating or facilitating these scope conditions for successful mentoring and advising. A mission that predictably had little impact in this regard was EUJUST Themis (2004-05), which was dispatched to Georgia after the Rose Revolution to help local authorities develop a 'governmental strategy guiding the reform process for all relevant stakeholders within the criminal justice sector' (Council of the European Union, 2004b). The implied role for the mission was that of arguer as the mandate neither gave the mission the means to play any other role, nor hinted at any EU intention to compel Georgia to adopt a particular reform blueprint. Yet the mission's success in drawing Georgian ministry personnel into a relationship of argumentation was limited, and only a part of the responsibility for that situation can be put on the in-theatre mission leadership. First and most importantly, Brussels operated with unrealistic assumptions about the mission staff required and the time needed to deliberate, together with senior Georgian ministry personnel, how best to reform the justice system. The mission had to make due with 10 international staff positions and was given one year to engage in a process of reasoned argumentation with local authorities about the content of a comprehensive reform strategy. In the event, neither proved sufficient, i.e., EUJUST Themis lacked the most basic infrastructure - human resources and time necessary for the logic of arguing to work.

Second, mission planning did not anticipate, and mission support and management were unable to respond effectively to, the fact that Themis competed with U.S. advisors who sought to persuade their Georgian counterparts to adopt a distinctly American legal framework (Helly, 2006). This professional rivalry created a politicised environment in which not the best argument but other considerations played the key role. Many of the new Georgian senior and mid-level ministry staff brought in by the administration of President Saakashvili had more lifeworld commonalities with Americans than with Europeans, not least because many, including the president himself, had been educated in the U.S. and because they saw America as a stronger supporter of Georgia than many key EU nations. The strength of the shared ideational background between Georgian officials and U.S. advisors is nicely illustrated by the fact that the Georgian ministry of interior at the time flew the U.S. flag next to the Georgian flag. The ministry did not display the EU flag. The pro-U.S. attitudes of the new Georgian administration gave American advisors a greater 'natural' authority and argumentative power in their interaction with local authorities than Themis staff. The mission leadership did not succeed in countering this disadvantage, say, by effectively appealing to Georgia's European destiny or by going beyond the logic of arguing. Although the mission representatives tried, they did not succeed in mobilising high-level political support and/or pressure in Brussels in support of their work in Georgia. Again, the responsibility for this situation can hardly be placed on the mission alone.

Incidentally, the rule-of-law mission EULEX Kosovo (2008) has experienced a similar transatlantic rivalry. EU and American advisors there have often squabbled over the merits of their respective legal and border security management systems and Kosovars often display a natural preference for U.S. recommendations (International Crisis Group, 2010). Yet these challenges faced by CSDP arguing missions pale in comparison to those encountered by many such missions deployed outside Europe. For example, social distance has been a great challenge to the effectiveness of the arguing mission EUPOL Afghanistan (2007). The huge cultural differences between Europeans and locals remove one of the key scope conditions for successful argumentation: a common or at least similar lifeworld of the participants. This highlights that the design of EUPOL Afghanistan is fundamentally flawed. In the absence of the conditions for successful arguing, CSDP decision-makers and administrators should have agreed on and designed a bargaining mission and endowed it with the capability to coerce or incentivise local interlocutors to reform the security sector in line with EU advice.

\section{CSDP Missions and Theories of Information Brokerage}

Information is a key, albeit somewhat under-theorised concept, in international relations. It is a crucial factor shaping actor preferences and beliefs concerning how to realise them. Information is a key variable in institutional theories of international cooperation under anarchy. When anarchy gains ground in the internal relations of countries and they collapse into conflict, information will often be a crucial factor in ending conflicts and building peace. Conflict management and conflict resolution theories thus pay particular attention to how the provision of unbiased information about the intentions, preferences, capabilities and conduct of opponents, and the associated reduction of uncertainty, can contribute to peace (Bercovitch, et al., 2008; Sandole, et al., 2009). Reflecting the importance of the connection between high-quality information and peace, the EU has recently 
added the role of information broker to its CSDP role repertoire.

Information brokerage can be defined as the collection and supply of information to the parties to a conflict with a view to helping them to manage or resolve their disagreements. In the case of CSDP missions, information brokerage is performed by means of two role types, monitor and mediator, with the latter role remaining very much a work in progress (Note 8). The key task of a monitor is to supply basic information to the conflict parties. Unbiased information about the actions, intentions and capabilities of opponents is typically scarce in conflict situations. This tends to be a problem in peace processes, which often resemble a Prisoner's Dilemma game. Mutual cooperation, although preferred to mutual defection, is not a stable equilibrium outcome. Actors may defect from the peace process or agreement in order to avoid what they fear most, being the party that cooperates while the opponent surreptitiously defects. By detecting and reporting instances of non-compliance, the monitor creates disincentives for cheating because potential double-dealers anticipate they will be caught. The role of monitor thus presupposes a rational-instrumental actor. Moreover, the monitor helps to detect unintentional non-compliance, which is due neither to a security dilemma nor to bad faith, but to factors such as ambiguous agreements or a lack of implementation capability (Chayes \& Chayes, 1993).

The role of mediator comes in different shapes and forms (Kleiboer, 1996; Touval and Zartman, 1989). In its most basic variety, the role is about generating and providing information to the conflict parties in order to facilitate the negotiation or peace implementation process by identifying negotiation space, clarifying the preference functions (subjective utilities and probabilities) of the parties and by adjudicating divergent interpretations of the situation. Mediating activities of this sort are designed to affect the cost-benefit calculations and strategies of opposing parties. Departing in part from the rational-actor model, mediation-as-information-brokerage may also aim at reconstructing the social-psychological dynamics of conflicts. For instance, mediators may help the parties to devise and put in place transparency-enhancing confidence-building measures that reduce distrust and suspicion among them. More muscular forms of mediation that go beyond information brokerage involve problem-solving, power-brokerage and the enforcement of agreements. For instance, mediators may propose compromise solutions, issue ultimatums or offer security guarantees to actors left vulnerable by a peace agreement. CSDPs, as designed to date, have had virtually no capabilities to perform such demanding mediation roles.

While there is a well-developed literature theorising mediation and peace, which specifies scope conditions for effective mediation-as-information brokerage (cf. Gilady \& Russett, 2002), no such literature exists with regard to monitoring. Yet since both roles fall into the category of information brokerage, it seems reasonable to assume that the same scope conditions apply to both. If so, the following conditions appear either to be necessary for, or conducive to, successful performance of the role of monitor or mediator. First, the third party playing the role must have the capacity to generate, process and disseminate reliable information. Second, role performance is facilitated if the third party is impartial, a characteristic that favours actors who are socially and geographically distant from the locus of a conflict. Finally, a reputation for even-handedness derived from past involvements in conflict resolution enhances the likelihood of effective role enactment. These are easy-to-use criteria analysts can use to evaluate the design and implementation of CSDP monitoring and mediation missions.

There have been two CSDP monitoring-cum-mediation missions to date. One met the principal scope conditions and thus successfully carried out its tasks. The other was deployed in the absence of proper scope conditions and its role performance suffered as a consequence. The Aceh Monitoring Mission (AMM; 2005-06) was tasked to monitor the peace agreement between the Indonesian government and the Free Aceh Movement (GAM), which had fought for the independence of that region. The assignment centred on monitoring the voluntary disarmament of the GAM and the pull-out of excess Indonesian military and police forces from the region. In cooperation with the Association of Southeast Asian Nations (ASEAN), the EU organised and ran the AMM. The EU managed to deploy and organise its monitors and equipment on the ground in record time. Once its information gathering capacity was up and running, the CSDP mission took pains to maintain impartiality. It went out of its way not to alienate either party, which had previously happened to the United Nations team when its involvement in resolving the conflict between Jakarta and East Timor was regarded by the former as failing to meet the impartiality standard. Going beyond monitoring, the AMM also took on a limited mediating role in order to resolve contentious issues, including amnesty cases, before they could disrupt the peace process. Again, it did so by maintaining its integrity. It based its judgements on strictly formal-legal, rather than political grounds, which reassured the government and GAM that the process was unbiased. With the help of the EU, the resolution of the conflict proceeded as planned. The mission successfully implemented its mandate.

Conversely, a perceived lack of impartiality has been one of the main obstacles preventing the EUMM from playing a more extensive monitoring and mediating role. The mission monitors the administrative boundary line 
only from the territory of Georgia because it is not allowed into South Ossetia and Abkhazia. Also, it plays only a limited mediating role in the context of its tasks as a co-convenor of the Incident Prevention and Response Mechanism between Georgia and South Ossetia, which brings together the two parties and Russian officials to deal with cross-border incidents such as shootings. Despite valiant attempts, the mission has not been able to extend its mediation role beyond localised trouble-shooting to affect the broader calculations and perceptions of the conflict parties. Both its limitations as a monitor and mediator are partly due to the fact that the mission is bound by the EU policy of rejecting the self-declared independence of the breakaway territories, which have been recognised by Russia. That stance makes the EUMM suspect in the eyes of the secessionists and Russia and limits its ability to carry out its role as information broker. The EUMM is a case in which Brussels gave a CSDP mission a mandate without putting in place the scope conditions for a successful role performance.

\section{Conclusion}

The paper has elaborated a toolkit for the systematic assessment of CSDP operations. The kit is derived from international relations theories and enables analysts to go beyond existing evaluation research of the CSDP, which is largely ad hoc and idiosyncratic in character. The kit classifies operations on the basis of their mandated activities. Common Security missions perform three roles: bargaining, arguing and information brokerage. These roles can be further broken down into specific actions: deterrence, compellence, facilitation of EU conditionality, mentoring, advising, training, monitoring and mediation. The toolkit identifies scope conditions that enable the successful completion of these actions. The paper uses examples to illustrate how the toolkit can be used to evaluate to what extent the roles assigned to CSDP operations by Brussels match the scope conditions present in theatre; to what extent Brussels has equipped its operations with the required role-specific policy instruments; and to what extent mission managers (in Brussels and in theatre) are successful in organising the means they have been given to increase the likelihood of successful mandate implementation.

Yet the toolkit is not without limitations. It is centred on mandates and limited to implementation-focused evaluations. These attributes helps those making CSDP decisions and implementing them improve the design and management of missions. Better designed and managed mission are likely to be more effective changemakers. Yet the toolkit offers no evaluation tools to probe the non-mission related factors accounting for CSDP impact on the ground. The elaboration of such tools remains a task for further research.

\section{Acknowledgements}

I would like to thank the editors for their useful comments on previous drafts. In addition, I would like to express my deep gratitude to Yannis Stivachtis for his encouragement to write the paper, his insightful comments on it and his incredible commitment to make this cooperative project a success.

\section{References}

Adler, E. (2010). Damned If You Do, Damned If You Don't: Performative Power and the Strategy of $\begin{array}{lllll}\text { Conventional and Nuclear Defusing. Security } & \text { Studies, 199-229. }\end{array}$ http://dx.doi.org/10.1080/09636411003796002

Art, R. J., \& Cronin, P. M. (2008). Coercive Diplomacy. In C. A. Crocker, F. O. Hampson, \& P. Aall (Eds.), Leashing the Dogs of War: Conflict Management in a Divided World. Washington, DC: United States Institute of Peace Press.

Bercovitch, J., Kremenyuk, V., \& Zartman, I. W. (2008). The SAGE Handbook of Conflict Resolution. London: Sage.

Bertin, T. (2008). The EU Military Operation in Bosnia. In M. Merlingen, \& R. Ostrauskaitè (Eds.), European Security and Defence Policy: An Implementation Perspective. London: Routledge.

Chalmers, D., Hadjiemmanuil, C., Monti, G., \& Tomkins, A. (2007). European Union Law. Cambridge: Cambridge University Press.

Chayes, A., \& Chayes, A. H. (1993). On Compliance. International Organization, 47(2), 175-205. http://dx.doi.org/10.1017/S0020818300027910

Checkel, J. T. (2000). Compliance and Conditionality. ARENA Working Paper 00/18, ARENA Centre for European Studies.

Checkel, J. T. (2001). Why Comply? Social Learning and European Identity Change. International Organization, 55(3), 553-588. http://dx.doi.org/10.1162/00208180152507551

Chivvis, C. S. (2010). EU Civilian Crisis Management: The Record So Far. Santa Monica, CA: Rand 
Corporation.

Council of the European Union. (2004a). Council Joint Action of 12 July on the European Union military operation in Bosnia and Herzegovina (2004/570/CFSP). Brussels, 12 July.

Council of the European Union. (2004b). Council Joint Action on the European Union Rule of Law Mission in Georgia, EUJUST THEMIS (2004/523/CFSP), Brussels, 28 June.

de Jonge Oudraat, C. (2008). Economic Sanctions and International Peace and Security. In C. A. Crocker, F. O. Hampson, \& P. Aall (Eds.), Leashing the Dogs of War: Conflict Management in a Divided World. Washington, DC: United States Institute of Peace Press.

Dobbins, J. (2008). Europe's Role in Nation Building. Survival, 50(3), 83-110. http://dx.doi.org/10.1080/00396330802173115

Dobbins, J., Jones, S. G., Crane, K., Chivvis, C. S., Radin, A., ... Goldsmith, B. W. (2008). Europe's Role in Nation-Building: From the Balkans to the Congo. Santa Monica, CA: Rand.

Dominguez, R. (2011). Security Governance in the Transatlantic Area: United States, NATO and the European Union. In F. Laursen (Ed.), The EU and Federalism: Polities and Policies Compared. Farnham: Ashgate.

Edgar, A. (2006). Habermas: The Key Concepts. London: Routledge.

Elster, J. (1991). Arguing and Bargaining in the Federal Convention and the Assemblée Constituante. Working Paper, Center for the Study of Constitutionalism in Eastern Europe.

Eriksen, E. O. (Ed.). (2005a). Making the European Polity: Reflexive Integration in the EU. London: Routledge.

Eriksen, E. O. (2005b). Reflexive Integration in Europe. In E. O. Eriksen (Ed.), Making the European Polity: Reflexive Integration in the EU. London: Routledge.

Fearon, J. (1994). Domestic Political Audiences and the Escalation of International Disputes. American Political Science Review, 88(3), 577-592. http://dx.doi.org/10.2307/2944796

Flessenkemper, T. (2008). EUPOL Proxima in Macedonia, 2003-05. In M. Merlingen, \& R. Ostrauskaite (Eds.), European Security and Defence Policy: An Implementation Perspective. London: Routledge.

Freedman, L. (2004). Deterrence. Cambridge: Polity Press.

Freedman, L. (2005). Deterrence: A Reply. The Journal of Strategic Studies, 28(5), $789-801$. http://dx.doi.org/10.1080/01402390500393944

George, A. L. (1997). Forceful Persuasion: Coercive Diplomacy as an Alternative to War. Washington, DC: US Institute of Peace.

George, A. L., \& Simons, W. (1994). The Limits of Coercive Diplomacy. Boulder, CO: Westview Press.

Giegerich, B. (2008). European Military Crisis Management: Connecting Ambition and Reality. Adelphi Paper, International Institute for Strategic Studies.

Gilady, L., \& Russett, B. (2002). Peacemaking and Conflict Resolution. In W. Carlsnaes, T. Risse, \& B. A. Simmons (Eds.), Handbook of International Relations. London: Sage. http://dx.doi.org/10.4135/9781848608290.n20

Ginsberg, R. H., \& Penksa, S. E. (2012). The European Union in Global Security: The Politics of Impact. Houndmills: Palgrave Macmillan. http://dx.doi.org/10.1057/9780230367524

Grabbe, H. (1999). A Partnership for Accession? The Implications of EU Conditionality for the Central and East European Applicants. Robert Schuman Centre Working Paper 12/99, European University Institute.

Grabbe, H. (2006). The EU's Transformative Power Europeanization Through Conditionality in Central and Eastern Europe. Houndmills: Palgrave.

Greenhill, K.M. and Major, S. 2006/7. The Perils of Profiling: Civil War Spoilers and the Collapse of Intrastate Peace Accords. International Security, 31(3), 7-40.

Grevi, G., Helly, D., \& Keohane, D. (Eds.) (2009). European Security and Defence Policy: The First 10 Years (1999-2009). Paris: EU Institute for Security Studies.

Habermas, J. (1984). The Theory of Communicative Action, Volume 1, Reason and The Rationalization of Society. Boston, MA: Beacon Press.

Helly, D. (2006). EUJUST Themis in Georgia: An Ambitious Bet on Rule of Law. In A. Nowak (Ed.), Civilian 
Crisis Management: The EU Way. Paris: EU Institute for Security Studies.

Howorth, J. (2007). Security and Defence Policy in the European Union. Houndmills: Palgrave.

International Crisis Group. (2010). The Rule of Law in Independent Kosovo. Europe Report 204.

Jakobsen, P. (1998). Western Ue of Coercive Diplomacy after the Cold War: A Challenge for Theory and Practice. London: Macmillan. http://dx.doi.org/10.1057/9780230373570

Jervis, R., Lebow, R. N., \& Stein, J. G. (Eds.). (1985). Psychology and Deterrence. Baltimore: The Johns Hopkins University Press.

Kirchner, E. (2013). Common Security and Defence Policy peace operations in the Western Balkans: impact and lessons learned. European Security, 22(1), 36-54. http://dx.doi.org/10.1080/09662839.2012.749865

Kirchner, E., \& Sperling, J. (2007). EU Security Governance. Manchester: Manchester University Press.

Kleiboer, M. (1996). Understanding Success and Failure of International Mediation. Journal of Conflict Resolution, 40(2), 360-389. http://dx.doi.org/10.1177/0022002796040002007

Landwehr, C., \& Holzinger, K. (2010). Institutional Determinants of Deliberative Interaction. European Political Science Review, 2(3), 373-400. http://dx.doi.org/10.1017/S1755773910000226

Lewis, J. (2005). The Janus Face of Brussels: Socialization and Everyday Decision Making in the European Union. International Organization, 59(4). http://dx.doi.org/10.1017/S0020818305050320

Long, A. (2008). Deterrence: Lessons from Six Decades of RAND Research - From Cold War to Long War. RAND Corporation.

Menon, A. (2009). Empowering Paradise? The ESDP at Ten. International Affairs, 85(2), 227-246. http://dx.doi.org/10.1111/j.1468-2346.2009.00791.x

Merlingen, M. (2009). The EU Police Mission in Bosnia and Herzegovina (EUPM). In G. Grevi, D. Helly, \& D. Keohane (Eds.), European Security and Defence Policy: The First 10 Years (1999-2009). Paris: EU Institute for Security Studies.

Merlingen, M. (2012). European Security and Defense Policy: What It Is, How It Works, Why It Matters. Boulder, CO: Lynne Rienner.

Merlingen, M., \& Ostrauskaitė, R. (Eds.). (2008). European Security and Defence Policy: An Implementation Perspective. London: Routledge.

Morgan, P. M. (2003). Deterrence Now. Cambridge: Cambridge University Press. http://dx.doi.org/10.1017/CBO9780511491573

Mühlmann, T. (2007). Police Restructuring in Bosnia-Herzegovina: Problems of Internationally-Led Security Sector Reform. Journal of Intervention and State Building, 1 (Supplement 1).

Mühlmann, T. (2008). The Police Mission EUPM in Bosnia, 2003-05. In M. Merlingen, \& R. Ostrauskaite (Eds.), European Security and Defence Policy: An Implementation Perspective. London: Routledge.

Newman, E., \& Richmond, O. P. (2006). Introduction. Obstacles to Peace Processes: Understanding Spoling. In E. Newman, \& O. P. Richmond (Eds.), Challengers to Peacebuilding: Managing Spoilers During Conflict Resolution. Tokyo: United Nations University Press.

Oliver, G. F. (2002). The Other Side of Peacekeeping: Peace Enforcement and Who Should Do It? In H. Langholtz, B. Kondoch, \& A. Wells (Eds.), International Peacekeeping: The Yearbook of International Peace Operations. Brill.

Risse, T. (2000). "Let's Argue!" Communicative Action in World Politics. International Organization, 54(1), 1-39. http://dx.doi.org/10.1162/002081800551109

Risse, T., \& Kleine, M. (2009). 'Deliberation in Negotiation'. Paper Presented at EUSA Conference (Los Angeles CA.

Sandole, D. J. D., Byrne, S., Sandole-Staroste, I., \& Senehi, J. (Eds.). (2009). Handbook of Conflict Analysis and Resolution. London: Routledge.

Schake, K. (2006). An American Eulogy for European Defence. In Anne Deighton with Victor Mauer, ed. Securing Europe? Implementing the European Security Strategy. Zürich: Center for Security Studies.

Schaub, G. (1998). Compellence: Resuscitating the Concept. In L. Freedman (Ed.), Strategic Coercion: 
Concepts and Cases. Oxford: Oxford University Press.

Schelling, T. C. (1990). The Strategy of Conflict. Cambridge, MA: Harvard University Press.

Schelling, T. C. (2008). Arms and Influence. New Haven: Yale University Press.

Schimmelfennig, F. (2008). EU Political Accession Conditionality After the 2004 Enlargement: Consistency and Effectiveness. Journal of European Public Policy, 15(6), 918-937. http://dx.doi.org/10.1080/13501760802196861

Schimmelfennig, F., \& Sedelmeier, U. (2004). Governance by Conditionality: EU Rule Transfer to the Candidate Countries of Central and Eastern Europe. Journal of European Public Policy, 11(4), 661-679. http://dx.doi.org/10.1080/1350176042000248089

Schmidt, V. A. (2010b). Taking Ideas and Discourse Seriously: Explaining Change Through Discursive Institutionalism as the Fourth 'New institutionalism'. European Political Science Review, 2(1), 1-25. http://dx.doi.org/10.1017/S175577390999021X

Schultz, K. A. (2004). Democracy and Coercive Diplomacy. Cambridge: Cambridge University Press.

Sechser, T. S. (2010). Goliath's Curse: Coercive Threats and Asymmetric Power. International Organization, 64, 627-660. http://dx.doi.org/10.1017/S0020818310000214

Sjursen, H. (2004). Changes to European Security in a Communicative Perspective. Cooperation and Conflict, 39(2), 107-128. http://dx.doi.org/10.1177/0010836704042864

Sjursen, H. (2006). What kind of Power? Journal of European Public Policy, 13(2), 169-181. http://dx.doi.org/10.1080/13501760500451584

Sperandei, M. (2006). Bridging Deterrence and Compellence: An Alternative Approach to the Study of Coercive $\begin{array}{lllll}\text { Diplomacy. } & \text { International } & \text { Studies } & \text { Review, } & \text { 253-280. }\end{array}$ http://dx.doi.org/10.1111/j.1468-2486.2006.00573.x

Stedman, S. J. (1997). Spoiler Problems in Peace Processes. International Security, 22(2), 5-53.

Stedman, S. J. (2000). Spoiler Problems in Peace Processes. In P. C. Stern, \& D. Druckman (Eds.), International Conflict Resolution After the Cold War. Washington, DC: National Academy Press.

Steunenberg, B., \& Dimitrova, A. (2007). Compliance in the EU Enlargement Process: The limits of Conditionality. European Integration Online Papers, 11.

Toje, A. (2008). The Consensus-Expectations Gap: Explaining Europe's Ineffective Foreign Policy. Security Dialogue, 39(1), 121-141. http://dx.doi.org/10.1177/0967010607086826

Touval, S., \& Zartman, W. I. (1989). Mediation in International Conflicts. In K. Kressel, \& D. Pruitt (Eds.), Mediation Research: The Process and Effectiveness of Third-Party Intervention. San Francisco, CA: Jossey-Bass.

Trauner, F. (2009). Deconstructing the EU's Routes of Influence in Justice and Home Affairs in the Western Balkans. Journal of European Integration, 31(1), 65-82. http://dx.doi.org/10.1080/07036330802503908

Vachudova, M. A. (2005). Europe Undivided: Democracy, Leverage and Integration after Communism. Oxford: Oxford University Press.

Walter, B. F. (1997). The Critical Barrier to Civil War Settlement. International Organization, 51(3), 337-340. http://dx.doi.org/10.1162/002081897550384

Walter, B. F. (2001). Committing to Peace: The Successful Settlement of Civil Wars. Princeton, NJ: Princeton University Press.

Williams, P. D. (2010). Enhancing Civilian Protection in Peace Operations: Insights from Africa, Research Paper no. 1, Africa Center for Strategic Studies, National Defense University Press.

Witney, N. (2008). Re-Energising Europe's Security and Defence Policy. European Council on Foreign Relations.

Zagare, F. C., \& Kilgour, D. M. (2000). Perfect Deterrence. Cambridge: Cambridge University Press. http://dx.doi.org/10.1017/CBO9780511491788 


\section{Notes}

Note 1. In his more recent writings, Howorth has adopted a more critical view of CSDPs.

Note 2. Interestingly, Kirchner does not use this framework in his recent evaluation of the contributions CSDP missions have made to peacekeeping and peacebuilding in the Western Balkans (Kirchner, 2013).

Note 3. According to the doctrine of implied powers, the EU has powers not only expressly granted to it by treaties but also, implicitly, such powers as are necessary to the achievement of its main objectives (Chalmers, et al., 2007: 211).

Note 4. This is a question of degree. There is general agreement in the literature on coercive bargaining that successful coercion requires the offer of some carrots, at a minimum the promise to stop the punishment when/if the target complies.

Note 5. Social power depends on a number of factors including the capacity to mobilise resources and networks and to impose one's narrative on the opponent (Adler, 2010: 204-5).

Note 6. CSDP operations rely on external funding to finance their reform projects. The Commission is one of the main funders of civilian CSDP projects.

Note 7. Under pressure from Brussels, the mission re-engineered its approach and six months into its one-year mandate adopted a project-driven reform strategy. With project development inevitably taking time, the mission only had just over four months to implement its new projects.

Note 8 . The peace and conflict studies literature typically subsumes the functions carried out by monitors under mediation. Mediation, in turn, may be conceptualized as a form of bargaining (Gilady and Russett, 2002).

\section{Copyrights}

Copyright for this article is retained by the author(s), with first publication rights granted to the journal.

This is an open-access article distributed under the terms and conditions of the Creative Commons Attribution license (http://creativecommons.org/licenses/by/3.0/). 